\title{
CORRECTIVE MAINTENANCE SKILLS REQUIREMENTS IN DVD HOME THEATRE FOR INTEGRATION INTO TECHNICAL COLLEGE CURRICULUM
}

\author{
Samson Onyeluka Chukwuedo, Anthony U. Ainetor \\ University of Benin, Nigeria \\ E-mail: onyeluka.chukwuedo@uniben.edu, ainetorantony@gmail.com
}

\begin{abstract}
As the world experiences changes in all facets of life, it is equally expected that the school curriculum should not remain static but change in the same direction. The electronic technology workshop practice in technical colleges in Nigeria has overtime been dominated with the teaching of practical skills in radio and television that are gradually phasing away in the electronic world, hence the need to upgrade it by integrating the practical contents of modern digital electronics, of which DVD home theatre sound system is one of the electronic gadgets. This study therefore determined the corrective maintenance skills requirements in DVD home theatre sound system necessary for improving the workshop practice of electronic technology via curriculum innovation in technical colleges. Three research questions were raised and answered using mean statistic, while one hypothesis was formulated and tested using t-test statistic. The descriptive survey research design was employed in the study. Afive point scaled questionnaire was the instrument used for data collection. The sample size was 164, comprising electronic technology teachers in universities and technical colleges and DVD home theatre sound system technicians in Edo State. The instrument was validated by experts and its reliability coefficient obtained using Cronbach's alpha formula was 0.876. It was found that the corrective maintenance skills requirements in DVD home theatre sound system necessary for integration into technical college curriculum for electronic technology workshop practice are skills in the use of tools and equipment to perform such maintenance, fault diagnosis skills in order to carry out the maintenance and the actual repairs (corrective maintenance) skills. It was therefore recommended that electronic technology teachers should be trained in the teaching of practical skills in maintenance of DVD home theatre sound system for capacity building.
\end{abstract}

Key words: DVD home theatre sound system, corrective maintenance, curriculum, electronic technology, technical college.

\section{Introduction}

One of the fields of study that has experienced continual advancement in recent times is electrical/electronic technology. Electrical/Electronic technology focuses on the understanding and application of electrical and electronic principles and technological processes, inherent in the production of electrical and electronic products, services and systems in order to improve the quality of life (Republic of South Africa, 2008). Electronic technology is the study of the scientific application of the flow of electrons to the functionality of electronics or electronic circuits, appliances and products. This may be generally categorized into analogue and digital electronics. In developing countries like Nigeria, digital electronics are widely used today, and they are manufactured and sold in different varieties.

Digital electronics deal with electronic products or appliances which function on the principle of logic gate and logic decisions with the use of integrated circuits (ICs) as their 
Samson Onyeluka CHUKWUEDO, Anthony U. AINETOR. Corrective maintenance skills requirements in DVD home theatre for integration into technical college curriculum

PROBLEMS

OF EDUCATION

IN THE $21^{\text {st }}$ CENTURY

Volume 66, 2015

main component (Theraja \& Sedha, 2009). Modern electronic products such as pocket personal computer (PC), personal digital assistant (PDA), MP3 players, digital cameras, digital camcorders, mobile phones, digital dictionaries and digital translators, compact disc (CD) players, digital versatile disc (DVD) players, liquid crystal display (LCD) television, DVD home theatre sound systems, laptop computers and the likes, make use of ICs extensively. Their structures and functions as well as the operations of their circuits are apparently similar because of the presence of ICs which serve as the complete electronic circuit in which both the active and passive components are fabricated on a tiny chip of silicon.

\section{Problem of Research}

In modern times the advancement in electronic appliances has drastically taken new dimensions that demand correspondent change in the curriculum contents of related technology education programmes. The technology or technical education programmes in Nigeria that is given the mandate to produce craftsmen or middle level manpower that will acquire practical skills in carrying out maintenance in technological devices is the technical college (Federal Republic of Nigeria, 2004). The electronic technology trade in technical colleges ensures that it produces graduate in the maintenance of electronic appliances, and one of such categories of electronics is the sound system. Over time, the static nature of the curriculum content of technical colleges has also affected the integration of the technology involve in the maintenance of modern sound systems. One sound system that is often used in most homes and offices in Nigeria is the DVD home theatre sound system, which also brings about corresponding frequency in the downtime of the appliances. Consequently, skilled manpower in carrying out the repairs is required, to avoid the use of trial and error by those technicians who apparently use mere transfer of knowledge to carry out such repairs. This must not be left in the hands of unskilled manpower, but the educational institution should produce the required manpower. If the curriculum content of technical colleges remains static, how can the required manpower for maintenance practice in this appliance be produces? It is, therefore, necessary that the requirements that will necessitate the integration of the corrective maintenance skills of DVD home theatre are determined. These form the baseline of this study.

\section{Research Focus}

There are fundamental devices upon which the function and designed of every digital electronics such as DVD home theatre sound systems depend; these are the building blocks of electronic appliances. The building blocks of digital electronics include the logic gates, adders, flip-flops, counters, registers, multiplexers, Schmitt triggers, encoders and decoders, microprocessors, microcontrollers, memories, application specific integrated circuits (ASIC), digital signal processor (DSP) and field-programmable gate array (FPGA) (Paton, 1998; Frey, 2000; IBM Family Science Team, 2001; Singmin, 2001; Tokhein, 2005; Theraja \& Sedha, 2009; Emant Pte Ltd, 2013). Prerequisite knowledge of these blocks will enhance competences in carrying out maintenance in DVD home theatre sound systems.

The DVD home theatre sound system is assembly of electrical/electronic devices or appliances that are connected together with the aid of cables or Bluetooth, as the case may be, in order to produce regular sound, picture or both via loudspeakers/woofer and/or television. It is commonly made up of connections involving the DVD player, loudspeakers, woofer, mixer, television and the likes to reproduce recorded sounds and/or pictures for human use. It brings pleasure in a home, office, disco hall, cinema hall and similar environs where sounds and pictures help to entertain listeners, viewers and dancers. The Solent Electronic Home (2011) stated that home theatre systems include the projector and its screen, the media player, BluRay, 
DVD or media server, the surround sound amplifier and the loudspeakers, the controller and the surrounding home automation system. The Projector and its Screen have to be able to provide an image which provides the required immersion effect for the audience. So the image has to be of good enough quality and big enough so that the film content becomes the most important thing in the room. Not all projectors are suitable for watching films, some are designed for presentations and do not have the speed of response required for a home cinema projector.

The operation and function of DVD home theatre sound system depend on voltage supply which fluctuates while the system is in use; hence digital electronics cannot function indefinitely when used in various places and conditions. Apart from voltage fluctuation, other factors such as temperature, dust and poor handling can lead to the breakdown of these products through one or more damaged components. These situations are common in Nigeria, and usually lead to breakdown or downtime of the appliances. Therefore, there is need for maintenance, repairs or replacement when the appliance is in downtime state. In most cases, when there is breakdown of electronics, repairs become the next option, especially in a developing country like Nigeria. Maintenance according to Ogbuanya, (2009) involves all the activities taken in order to prolong the service life of the item. There are basically three types of maintenance, which are preventive, predictive and corrective maintenance. The emphasis of this study is on corrective maintenance since the study focuses on workshop practice which involves majorly the teaching and learning of practical skills in the design, construction and repairs of circuits, devices or appliances.

Corrective maintenance is sometimes referred to as equipment repair maintenance, and it involves all actions needed or carried out to restore an item to its functional order (Ogbuanya, 2009). It can be used interchangeably as breakdown maintenance or repairs. Repairs in the view of Bridgestone Michellin Pirelli (2013) are services that are required or necessary when something on a system is not working properly or may have worn to the point where a replacement is required to maintain the performance of the system. According to Australian Taxation Office (2012) repairs mean work to make good or remedy defects in, damage to or deterioration of the property. For example, work done in repairing electrical/electronic appliances or machinery can be termed repairs. Repairs in the context of this study are the task and activities taken for the restoration of a broken, damaged or failed component, device, equipment, parts, or appliance to an acceptable operating or stable state. In order that these products are properly repaired at their downtime there is need for trained competent manpower. These tasks are the requirements in carrying out the corrective maintenance, and these include ability to select and use the appropriate tools and equipment for fault detection and remediation, ability to diagnose faults and the ability to repair the appliance.

One of the educational programmes where maintenance skills in electronic appliances can be obtained in Nigeria is technical education, of which technical college is one of such institutions. Nwachukwu, Bakare and Jika (2011) affirmed that technical college provides students through training with the relevant and adequate knowledge, skills and attitude for employment under the guidelines of a teacher in related occupations. In order to achieve these objectives, various trades or occupations are learnt at technical institutions. Ede, Miller and Bakare (2010) identified that students undertaking technical education programmes are trained in auto mechanics, woodwork, plumbing, electrical installation and maintenance work, radio and television (RTV) and electronics, computer craft and mechanical trades. In technical college curriculum, maintenance practices are generally taught via workshop practice module.

Workshop practice is a common practical class for acquisition of practical skills in technical education programmes. It is a period where students are exposed to practical. It is also organized to expose the students to the rudiments and procedures of design, construction, implementation and repairs of devices, appliances or system in the different subject areas of technical education. This study is delimited to workshop practice in electronic technology of 
Samson Onyeluka CHUKWUEDO, Anthony U. AINETOR. Corrective maintenance skills requirements in DVD home theatre for integration into technical college curriculum

PROBLEMS

OF EDUCATION

IN THE $21^{\text {st }}$ CENTURY

Volume 66, 2015

10

technical colleges in Nigeria. The electronic technology workshop practice places emphasis on the design, construction and repair of electronic circuits, devices or appliances. In technical colleges, more emphasis is placed on repairs or corrective maintenance of electronic appliances, apparently because the design and construction of electronic appliances may be higher than or beyond the cognitive or intellectual ability and internalization of the students, or that majority of these appliances are not usually manufactured in Nigeria.

The RTV trade in technical colleges in Nigeria enables learners to acquire theoretical and practical skills in maintenance of radio and television receivers. This trade has recently been renamed RTV and Electronic works (National Business and Technical Examination Board, NABTEB, 2007). This calls for improvement in the content of the trade. The common corrective maintenance skills taught in most technical colleges in Nigeria, under the RTV and Electronic works trade is in cathode ray tube (CRT) television, cassette deck and turn table stereo sound systems. The question here is how long will technical colleges in Nigeria continue retrospectively in delivering its curriculum? Technology has improved dramatically, hence the need for improvement in the curriculum of electronic technology workshop practice in technical colleges so that its graduates can compete favorably in the world of work. These problems call for this paper. One of the most commonly used sound systems in Nigeria in recent times is the DVD home theatre sound system. Most homes and offices in Nigeria have continued to replace their sound systems with sophisticated and modern DVD home theatre sound systems. It is therefore expected that the number of these appliances that will breakdown will continue to increase, hence it is necessary that the curriculum of the formal TVET programmes, especially technical college where lower middle manpower is produced, be improved to integrate the teaching and learning of corrective maintenance of modern digital electronic appliances such as the DVD home theatre sound system. Besides, the ability of electronic technology graduates of technical colleges to effectively and efficiently repair DVD home theatre sound system will serve as viable entrepreneurial innovation to them. The foregoing so far are the problems that posed the researcher to embark on this study, and they form the bases behind this study. The study therefore investigated corrective maintenance skills in DVD home theatre sound system necessary to improve the workshop practice of electronic technology curriculum in technical colleges for demand driven graduates.

The main purpose of this study was to determine the requirements in corrective maintenance skills in DVD home theatre sound systems necessary for integration into technical college curriculum for workshop practice in Nigeria. The study specifically identified the tools and equipment required to carry out fault diagnosis/repairs, the possible faults in DVD home theatre sound system, and the practical skills in the repairs of DVD home theatre sound system that are necessary to be integrated into the curriculum of electronic technology trade for workshop practice. In line with the objectives of the study, the research questions raised and answered in this study are: (a) what are the tools and equipment required for fault detection/ repairs in DVD home theatre sound system necessary for integration into electronic technology workshop practice curriculum in technical colleges? (b) what faults diagnosis requirements in DVD home theatre sound system are necessary for integration into electronic technology workshop practice curriculum in technical colleges? (c) what are the practical skills in the actual repairs of DVD home theatre sound system necessary for integration into electronic technology workshop practice curriculum in technical colleges? Out of these, research question three was hypothesize as "there is no significant difference between the mean responses of electronic technology teachers and the DVD home theatre sound system technicians as regards the practical skills in the actual repairs of DVD home theatre sound system necessary for improving electronic technology curriculum of technical colleges for workshop practice". 


\section{Methodology of Research}

$\mid$\begin{tabular}{l} 
PROBLEMS \\
OF EDUCATION \\
IN THE 21 $1^{\text {st }}$ CENTURY \\
Volume 66, 2015 \\
\hline 11
\end{tabular}

General Background of Research

The study employed the descriptive survey research design in which the opinions of a representative sample of DVD home theatre sound system technicians that repair the appliance and the electronic technology teachers in universities and technical colleges in Edo State were sought in order to make generalization and description of the findings to other electronic technology trades in technical colleges in Nigeria. According to Gall, Gall and Borg (2007) descriptive survey makes use of questionnaire or interview for data collection. Similarly, in descriptive survey research, the opinions of respondents are sought with the use questionnaire, observation, interview and other related instrument for data collection (Nworgu, 2006; Uzoagulu, 2011). The descriptive survey research adopted in this study has to do with use of questionnaire such that the opinion of electronic technology teachers and electronic technicians in Nigeria were sought to determine the corrective maintenance skills requirements in DVD home theatre sound system that are relevant for integration into technical college's curriculum. The maintenance skills in DVD home theatre sound system has not been reflected in the curriculum of technical colleges, hence the need to determine, from the opinion of experts the skills and requirements that will necessitate the integration.

\section{Sample of Research}

The sample size of the study was 164 , which comprised all the 22 electronic technology teachers, and 142 registered DVD home theatre sound system technicians. No sampling technique was employed in selecting the electronic technology teachers since all were used for data collection because of the manageable size, but convenience sampling techniques was employed in selecting the 142 electronic technicians. Convenience sampling was employed because the researchers administered the instrument to only the technicians who were easily reached without taking any criterion into consideration (Gall, Gall \& Borg, 2007). This sample was drawn from a pool of 22 electronic technology teachers and 221 registered electronic technicians who have the technical know-how on the technology and corrective maintenance skills of DVD home theatre sound system in Edo State, Nigeria.

\section{Instrument and Procedures}

The instrument used for data collection was a five point scaled questionnaire made up of three sections which were in line with the three research questions. The three sections were scaled very highly necessary (VHN), highly necessary (HN), averagely necessary (AV), slightly necessary $(\mathrm{SN})$ and not necessary $(\mathrm{NN})$. The response categories were assigned numerical values of 5, 4, 3, 2 and 1 respectively for statistical coding and analysis. The questionnaire was validated by three experts who consist of two electronic technology lecturers and one electronic technician. A reliability coefficient of 0.876 was determined using internal consistency method, by applying Cronbach's alpha formula. Data collection was done by the researchers with the help of two research assistants, and this lasted for a period of four months which was from November 2013 to March 2015. This was to ensure adequate and effective data collection since the technicians were relatively difficult to be located and/or found available in their workshops or in some situations where the respondents were not willing to fill the questionnaire at point of administration, they are given more time to do so. Additionally, where the questionnaire could not be retrieved say as a result of misplacement on the part of the respondents, they are also given another copy of the questionnaire to fill. 
Samson Onyeluka CHUKWUEDO, Anthony U. AINETOR. Corrective maintenance skills requirements in DVD home theatre for integration into technical college curriculum

OF EDUCATION

IN THE $21^{\text {st }}$ CENTURY

Volume 66,2015

Data Analysis

The data collected were analyzed using mean, standard deviations and two independent sample t-test statistics. The mean was used to answer the research questions while the t-test was used to test the hypothesis at .05 level of significant. The standard deviation was used to determine the extent to which the responses were clustered to or deviated from the mean responses. The decision rule for the research questions was based on real limit of values. Items with mean responses within the range of the real limit of values: 1.00 to $1.49,1.50$ to $2.49,2.50$ to $3.49,3.50$ to 4.49 and 4.50 to 5.00 were remarked VHN, HN, AN, SN and NN respectively. For the hypothesis, the decision rule was based on alpha value of .05, such that if the probability (p) value is less than or equal to alpha value of .05, the null hypothesis is rejected, but if the $\mathrm{p}$-value is greater than the alpha value, the null hypothesis is retained.

\section{Results of Research}

The results of the study are presented and analyzed in order of research questions and hypothesis. They are respectively presented in tables 1, 2, 3 and 4 for research questions 1, 2, 3 and one hypothesis.

Table 1. Mean and standard deviation of the necessary tools and equipment for corrective maintenance of DVD home theatre sound system.

\begin{tabular}{|c|c|c|c|c|c|c|}
\hline \multirow[b]{2}{*}{$\mathrm{S} / \mathrm{N}$} & \multirow[b]{2}{*}{ Tools and Equipment } & \multirow{2}{*}{$\begin{array}{l}\text { Teachers N=22 } \\
\text { Mean }_{1}\end{array}$} & \multirow{2}{*}{$\begin{array}{l}\text { Technicians } \\
\mathrm{N}=142 \\
\text { Mean }_{2}\end{array}$} & \multicolumn{2}{|c|}{ Aggregate } & \multirow[b]{2}{*}{ Remarks } \\
\hline & & & & Mean & SD & \\
\hline 1 & Screw Driver & 4.80 & 4.82 & 4.81 & .333 & $\mathrm{VHN}$ \\
\hline 2 & Pliers & 4.66 & 4.82 & 4.74 & .308 & " \\
\hline 3 & Cutter & 4.61 & 4.59 & 4.60 & .269 & $"$ \\
\hline 4 & Hard and Flexible Boards & 4.38 & 4.52 & 4.45 & .585 & $\mathrm{HN}$ \\
\hline 5 & Multimetres & 4.91 & 4.93 & 4.92 & .329 & VHN \\
\hline 6 & Soldering Iron & 4.86 & 4.90 & 4.88 & .474 & $"$ \\
\hline 7 & Soldering Lead & 4.58 & 4.80 & 4.69 & .409 & $"$ \\
\hline 8 & Lead Sucker & 4.71 & 4.47 & 4.59 & .324 & " \\
\hline 9 & Soldering Paste & 4.69 & 4.73 & 4.71 & .332 & $"$ \\
\hline 10 & Hand Drilling Machine/Puncher & 3.60 & 4.00 & 3.95 & .852 & $\mathrm{HN}$ \\
\hline 11 & Allen Key/Torxy Driver & 4.80 & 4.74 & 4.77 & .415 & VHN \\
\hline 12 & Blower & 4.86 & 4.90 & 4.88 & .397 & $"$ \\
\hline 13 & Brushes & 4.90 & 4.88 & 4.89 & .479 & $"$ \\
\hline 14 & Spirit & 4.36 & 4.40 & 4.38 & .521 & $\mathrm{HN}$ \\
\hline 15 & Magnifying Lens & 4.43 & 4.47 & 4.45 & .941 & $"$ \\
\hline 16 & Microscope & 3.64 & 3.62 & 3.63 & .963 & $"$ \\
\hline 17 & Hand Glove & 3.82 & 3.90 & 3.86 & .873 & $"$ \\
\hline 18 & Board Holder & 3.90 & 3.92 & 3.91 & .941 & $"$ \\
\hline 19 & Adjustable DC Power Supply & 4.77 & 4.81 & 4.79 & .701 & VHN \\
\hline 20 & Forceps & 4.73 & 4.81 & 4.77 & .620 & $"$ \\
\hline 21 & Copper Wire & 4.92 & 4.98 & 4.95 & .464 & $"$ \\
\hline 22 & Rework/Fire Station & 4.71 & 4.77 & 4.74 & .584 & $"$ \\
\hline 23 & Signal Generator & 4.12 & 3.96 & 4.04 & .888 & $\mathrm{HN}$ \\
\hline 24 & AC Generator & 3.53 & 3.61 & 3.57 & .965 & $"$ \\
\hline 25 & Oscilloscope & 3.66 & 3.80 & 3.73 & .631 & $"$ \\
\hline
\end{tabular}


The results of the data presented in Table 1 show that the mean responses of teachers and technicians ranged from 3.52 to 4.92 and 3.61 to 4.98 respectively. The table shows that the aggregate mean values ranged from 3.57 to 4.92 while the aggregate values of the standard deviation ranged from .308 to .965 . The mean values reveal that 15 tools/equipment are very highly necessary for integration into electronic technology curriculum for teaching maintenance skills of DVD home theatre sound systems during workshop practice, while 10 tools/equipment are highly necessary for integration into the curriculum, so as to improve skill acquisition in workshop practice of electronic technology in technical colleges. These simply mean that the skills in the use of the identified tools and equipment are requirements in corrective maintenance of DVD home theatre sound system for integration into technical college curriculum.

Table 2. Mean and standard deviation of fault diagnosis required for corrective maintenance in DVD home theatre sound system.

\begin{tabular}{|c|c|c|c|c|c|c|}
\hline \multirow[b]{2}{*}{$\mathrm{S} / \mathrm{N}$} & \multirow[b]{2}{*}{ Fault Diagnosis Requirements } & \multirow{2}{*}{$\begin{array}{l}\text { Teachers } \\
\mathrm{N}=22\end{array}$} & \multirow{2}{*}{$\begin{array}{l}\text { Technicians } \\
\mathrm{N}=142 \\
\text { Mean }_{2}\end{array}$} & \multicolumn{2}{|c|}{ Aggregate } & \multirow[b]{2}{*}{ Remarks } \\
\hline & & & & Mean & SD & \\
\hline 26 & Power not coming up (power failure) & 4.68 & 4.78 & 4.73 & .467 & VHN \\
\hline 27 & DVD player failure/not responding & 4.20 & 4.44 & 4.32 & .535 & $\mathrm{HN}$ \\
\hline 28 & Bluetooth failure/not responding & 3.55 & 3.89 & 3.72 & .847 & “ \\
\hline 29 & Lens not responding & 3.98 & 4.33 & 4.11 & .503 & “ \\
\hline 30 & Dead motherboard & 4.65 & 4.63 & 4.64 & .459 & VHN \\
\hline 31 & Pictures/images not transmitting & 4.63 & 4.67 & 4.65 & .536 & $"$ \\
\hline 32 & Audio failure & 4.69 & 4.73 & 4.71 & .582 & “ \\
\hline 33 & USB ports not responding & 4.58 & 4.48 & 4.53 & .621 & " \\
\hline 34 & Error in disc reading & 4.41 & 4.47 & 4.44 & .509 & $\mathrm{HN}$ \\
\hline 35 & Remote control not responding & 4.50 & 4.28 & 4.39 & .643 & “ \\
\hline 36 & Noisy/humming sound production & 4.66 & 4.38 & 4.52 & .612 & VHN \\
\hline 37 & VGA assembly failure & 3.97 & 4.49 & 4.23 & .821 & $\mathrm{HN}$ \\
\hline 38 & Wireless speakers not responding & 3.56 & 3.80 & 3.68 & .777 & “ \\
\hline 39 & HDTV connection not responding & 3.20 & 3.90 & 3.55 & .901 & $"$ \\
\hline 40 & Bose 3-2-1 system not responding & 3.82 & 4.14 & 3.98 & .851 & “ \\
\hline 41 & Failure in picture transmission & 3.74 & 4.00 & 3.87 & .866 & “ \\
\hline 42 & No transmission of sound to speakers & 3.59 & 3.75 & 3.67 & .787 & “ \\
\hline 43 & No response in the woofer & 3.63 & 4.03 & 3.83 & .895 & " \\
\hline
\end{tabular}

Source: Field Study, 2013-2014

The data presented in Table 2 reveal that the mean responses of teachers and technicians ranged from 3.20 to 4.69 and 3.75 to 4.78 respectively. The aggregate mean responses ranged from 3.55 to 4.73 while the aggregate values of the standard deviation ranged from .459 to .901 . The table shows that the teaching of six of the identified faults in DVD home theatre sound system faults are very highly necessary for integration into electronic technology curriculum for workshop practice in technical colleges, while the teaching of 12 of the identified faults are highly necessary for workshop practice in electronic technology. Summarily, it is necessary to teach faults diagnosis in DVD home theatre sound system in order to improve workshop practice of electronic technology curriculum in technical colleges. 
Samson Onyeluka CHUKWUEDO, Anthony U. AINETOR. Corrective maintenance skills requirements in DVD home theatre for integration into technical college curriculum

OF EDUCATION

IN THE $21^{\text {st }}$ CENTURY

Volume 66, 2015

Table 3. Mean and standard deviation of practical skills in the actual repairs of DVD home theatre sound system.

\begin{tabular}{|c|c|c|c|c|c|c|}
\hline \multirow[b]{2}{*}{$\mathrm{S} / \mathrm{N}$} & \multirow[b]{2}{*}{ Repair Skills in DVD Home Theatre } & \multirow{2}{*}{$\begin{array}{l}\text { Teachers } \\
\mathrm{N}=22\end{array}$} & \multirow{2}{*}{$\begin{array}{l}\text { Technicians } \\
\mathrm{N}=142 \\
\text { Mean }_{2}\end{array}$} & \multicolumn{2}{|c|}{ Aggregate } & \multirow[b]{2}{*}{ Remarks } \\
\hline & & & & Mean & SD & \\
\hline 44 & Assembling of the DVD home theatre player & 4.88 & 4.94 & 4.91 & .340 & VHN \\
\hline 45 & $\begin{array}{l}\text { Dissembling of the DVD home theatre } \\
\text { player }\end{array}$ & 4.91 & 4.89 & 4.90 & .334 & " \\
\hline 46 & $\begin{array}{l}\text { Ability to test capacitors, diode, transistors } \\
\text { with multimetre }\end{array}$ & 4.77 & 4.83 & 4.80 & .401 & " \\
\hline 47 & $\begin{array}{l}\text { Removal and replacement of the main } \\
\text { board }\end{array}$ & 4.45 & 4.51 & 4.48 & .504 & $\mathrm{HN}$ \\
\hline 48 & Fixing faults relating to no sound distribution & 3.89 & 4.19 & 4.04 & .631 & " \\
\hline 49 & Dissemble Bose acoustimass & 4.24 & 4.52 & 4.38 & .489 & " \\
\hline 50 & Fixing the DVD player lens problems & 3.84 & 4.20 & 4.02 & .522 & " \\
\hline 51 & Removal and installation of cooling fan & 4.23 & 4.45 & 4.34 & .478 & " \\
\hline 52 & $\begin{array}{l}\text { How to set up ARC and HDMI control set- } \\
\text { tings to TV }\end{array}$ & 4.43 & 3.99 & 4.21 & .456 & " \\
\hline 53 & Fixing faults in power board & 3.57 & 4.03 & 3.80 & .672 & $"$ \\
\hline 54 & Removal and replacement of drives & 4.57 & 4.15 & 4.36 & .520 & $"$ \\
\hline 55 & $\begin{array}{l}\text { Fixing no picture/image transmission } \\
\text { problem }\end{array}$ & 3.99 & 4.11 & 4.05 & .553 & " \\
\hline 56 & Repair Bose 3-2-1 & 4.28 & 4.36 & 4.32 & .508 & $"$ \\
\hline 57 & Repair AV receiver & 4.03 & 3.07 & 3.95 & .519 & $"$ \\
\hline 58 & Fixing sticking door problems & 3.52 & 3.88 & 3.70 & .784 & " \\
\hline 59 & Fix faults in USB compartment & 4.01 & 3.81 & 3.91 & .668 & " \\
\hline 60 & Fixing faults in Bluetooth sensitivity & 3.80 & 4.12 & 3.96 & .631 & " \\
\hline 61 & Fixing faults in the VGA assembly & 3.52 & 4.12 & 3.82 & .897 & " \\
\hline 62 & $\begin{array}{l}\text { Removing and replacing diode, resistors, } \\
\text { transistors, ICs }\end{array}$ & 4.17 & 4.33 & 4.25 & .548 & $"$ \\
\hline 63 & Rectify hum sound and noise & 4.28 & 4.43 & 4.36 & .554 & " \\
\hline 64 & Fix USB port & 4.02 & 3.62 & 3.82 & .690 & " \\
\hline 65 & Fixing wireless faults in speakers & 4.11 & 4.21 & 4.16 & .496 & " \\
\hline 66 & Repair faulty remote control & 3.81 & 4.01 & 3.91 & .514 & " \\
\hline 67 & Repair FM and AM tuner circuit & 3.99 & 3.77 & 3.88 & .605 & " \\
\hline 68 & Fixing faults in woofer & 3.54 & 3.86 & 3.70 & .737 & " \\
\hline 69 & Fixing faults in video/audio terminals & 4.15 & 4.17 & 4.16 & .654 & $"$ \\
\hline 70 & Repair faults in AC power terminal & 4.20 & 4.16 & 4.18 & .690 & " \\
\hline 71 & Rectify cracking sound/noise & 4.03 & 3.83 & 3.93 & .628 & " \\
\hline 72 & Program DIRECTV remote to TV & 3.76 & 4.02 & 3.89 & .562 & " \\
\hline
\end{tabular}

Source: Field Study, 2013-2014

Data presented in Table 3 show that the mean responses of teachers and technicians ranged from 3.52 to 4.91 and 3.07 to 4.94 respectively. The results show that the aggregate mean responses ranged from 3.70 to 4.90 while the aggregate values of the standard deviation ranged from .334 to .897 . The mean values show that three corrective maintenance skills in the repairs of DVD home theatre sound system are very highly necessary while 26 of the skills are highly necessary for integration into electronic technology curriculum for workshop practice in technical colleges. The result summarily reveals that it is necessary that the teaching of corrective maintenance skills in DVD home theatre sound system be integrated into electronic technology curriculum of technical colleges for improved workshop practice.

Hypothesis: There is no significant difference between the mean responses of electronic technology teachers and the DVD home theatre sound system technicians as regards the 
Samson Onyeluka CHUKWUEDO, Anthony U. AINETOR. Corrective maintenance skills requirements in DVD home theatre for integration into technical college curriculum

practical skills in the actual repairs of DVD home theatre sound system necessary for improving electronic technology curriculum of technical colleges for workshop practice.

Table 4. t-test analysis between teachers and technicians on corrective maintenance skills in DVD home theatre sound system for electronic technology curriculum.

\begin{tabular}{|c|c|c|c|c|c|c|c|c|}
\hline \multirow[b]{2}{*}{ Variables } & \multirow[b]{2}{*}{ Respondents } & \multirow[b]{2}{*}{$\mathbf{N}$} & \multicolumn{2}{|c|}{ Aggregate } & \multirow[b]{2}{*}{ df } & \multirow[b]{2}{*}{ t-value } & \multirow[b]{2}{*}{$\mathrm{p}$-value } & \multirow[b]{2}{*}{ Decision } \\
\hline & & & Mean & SD & & & & \\
\hline \multirow{4}{*}{$\begin{array}{l}\text { Corrective maintenance } \\
\text { Skills in DVD home theatre } \\
\text { system }\end{array}$} & & & & & 162 & .679 & .612 & NS \\
\hline & Teachers & 22 & 4.10 & .538 & & & & \\
\hline & Technicians & 142 & 4.02 & .511 & & & & \\
\hline & Total & 164 & & & & & & \\
\hline
\end{tabular}

Source: Field Study, 2013-2014 NS: not significant

The data presented in Table 4 show that the aggregate mean of the teachers' and technicians' responses are 4.10 and 4.02 respectively. The respective standard deviations are .538 and .511 . At a degree of freedom (df) of 70, the t-value of .679 is not significant at a p-value of .612. Since the p-value is greater than the alpha value (.05), the null hypothesis is upheld. Therefore, the mean responses of the teachers and the technicians did not significantly differ as regards the corrective maintenance skills necessary for improving the electronic technology curriculum of technical colleges for workshop practice.

\section{Discussion}

Data generated to identify the tools and equipment required for teaching corrective maintenance in DVD home theatre sound system in technical college in Nigeria showed that all the identified tools and equipment in this study are necessary for the integration into the curriculum for workshop practice. This corroborates the findings of Omofonmwan and Chukwuedo (2013) who found that the tools and equipment needed for skill acquisition in the repairs of digital electronics in the National Open Apprenticeship Scheme (NOAS) of the National Directorate of Employment (NDE) in Edo State are not sufficiently provided to the trainees. The determined tools and equipment are not entirely different from those used in carrying out corrective maintenance of other digital electronic appliances. Literature such as Tokhein, (2005) and Theraja, \& Sedha, (2009) have identified these tools and equipment as those needed in the technology of electronic devices and appliance.

The results of research question two identified the various fault diagnosis in DVD home theatre sound system that are necessary to be a requirement for integration into the curriculum of technical colleges for electronic technology workshop practice. Ohanu (2013) and Ibezim, Ohanu and Shodeinde (2014) also identified the faults that are available in LCD television and mobile phones hardware respectively that are necessary for teaching and learning in electronic technology programmes in Nigeria. This can also be likened to the findings of Chukwuedo and Nwachukwu (2014) who found that detection and remediation of possible faults in mobile phones are important skills for training prospective electronic technologist.

The data generated for research question 3 and test corresponding hypothesis revealed the repair skills in DVD home theatre sound system that are necessary for integration into electronic technology curriculum of technical colleges. The findings are in consensus with that of Ohanu (2013) and Ibezim, Ohanu and Shodeinde (2014) who respectively found the skills in maintenance of LCD television and mobile phone hardware for electronic technology 
Samson Onyeluka CHUKWUEDO, Anthony U. AINETOR. Corrective maintenance skills requirements in DVD home theatre for integration into technical college curriculum

PROBLEMS

OF EDUCATION

IN THE $21^{\text {st }}$ CENTURY Volume 66, 2015

16

programme in technical colleges and tertiary institutions. In the same way, the findings of the hypothesis of this study corroborate with the findings of Ibezim, Ohanu and Shodeinde (2014) who found that electronic technology lecturers in tertiary institutions did not differ in their mean responses as regards mobile phone hardware repairs for integration into the curriculum of electronic technology.

\section{Conclusions}

Technology is not static, likewise curriculum. The two phenomena are dynamic, as technology advances, it is necessary that the curriculum of the school is improved to integrate the skills from innovative technology. This study found that the requirements of corrective maintenance skills in DVD home theatre sound system should be integrated into electronic technology curriculum of technical colleges for improved workshop practice in RTV and electronic trade of electronic technology in technical colleges in Nigeria. It was therefore concluded that skills in the use of tools and equipment, fault diagnosis and the repairs of DVD home theatre sound system are necessary for integration into electronic technology curriculum in technical colleges in Nigeria. In line with the findings of this study, it is recommended that:

- $\quad$ attempts should be made by educational stakeholders and curriculum planners to integrate the relevant competences/contents in DVD home theatre sound system for electronic technology curriculum in technical colleges in Nigeria,

- electronic technology teachers of technical colleges should be trained in maintenance practices in DVD home theatre sound system for capacity building; and

- government in collaboration with NGOs should provide the materials, tools and equipment necessary for teaching these skills in technical colleges.

\section{References}

Australian Taxation Office (2012). Rental properties-claiming repairs and maintenance expenses. Retrieved from http//www.ato.gov.au/individuals/content.aspx?doc=/content/00183233.htm.

Bridgestone Michellin Pirelli (2013). Difference between maintenance and repairs. Retrieved from http// www.tiresplus.com/learn/diff.jps.

Chen, W. (2005). The electronic engineering handbook. U.S.A.: Academic Press.

Chukwuedo, S. O., \& Nwachukwu, C. E. (2014). Maintenance practices in mobile phones for training prospective electronic technologists. Journal of Research in National Development, 12 (1), $215-$ 222.

Ede, E. O., Miller, I. O., \& Bakare, J. A. (2010). Work skills improvement needs of graduates of technical colleges in machine shop practice for demand driven employment in South West Zone of contemporary Nigeria. Nigerian Vocational Association Journal, 15 (1), 18-27.

Emant Pte Ltd. (2013). Digital/analog electronic tutorial. Retrieved 11/03/13, from http://electronicscourse.com/

Frey, E. R. (2000). Lecture note for digital electronics. Physics Department, University of Oregon. U.S.A.

Gall, M. D., Gall, J. P., \& Borg, W. R. (2007). Education research: An introduction. New York: Pearson International Inc.

Ibezim, N. E., Ohanu, I. B., \& Shodeinde, A. O. (2014). Capacity building needs of electronic technology lecturers for integration of mobile phone hardware repair into the electronic curriculum. Journal of Education and Practice, 5 (5), 80-87. Retrieved 04/04/14, from http://www.iiste.org.

IBM Family Science Team (2001). Introduction to digital electronics. Retrieved 11/03/13, from http:// www.watson.ibm.com/leo/introelect/IntroElectro_handout.pdf.

NABTEB (2007). National business and technical examination board syllabuses for engineering trade examination (based on NBTE modular curriculum). ETF Intervention in TVET.

Nwachukwu, C. E., Bakare, J. A., \& Jika, F. O. (2011). Effective laboratory safety practices skills required by electrical and electronic students of technical colleges in Ekiti State. Nigerian Vocational Association Journal, 16 (1), 141-147. 
Samson Onyeluka CHUKWUEDO, Anthony U. AINETOR. Corrective maintenance skills requirements in DVD home theatre for integration into technical college curriculum

Nworgu, B. G. (2006). Educational research: Basic issues \& methodology. Nigeria: Wisdom Publishers Limited.

Ogbuanya, T. C. (2009). Energy and technology of home appliances. Enugu: Cheston Ltd.

Ohanu, I. B. (2013). Maintenance practices required for Liquid Crystal Display (LCD) television by electronic technicians in Anambra State (Unpublished master's thesis). University of Nigeria, Nsukka, Nigeria.

Omofonmwan, G. O. \& Chukwuedo, S. O. (2013). Availability and adequacy of resources for skill acquisition in digital electronics repairs in the national open apprenticeship scheme in Edo State, Nigeria. International Journal of Vocational and Technical Education, 5 (6), 110-116. Retrieved 19/02/14, from http://www.academicjournals.org/IJVTE.

Paton, B. (1998). Fundamentals of digital electronics. Retrieved 11/03/13, from http://www.sensor.phys. dal.

Republic of South Africa (2008). National curriculum: Electrical technology. Retrieved 17/05/14, from http://curriculum.wcape.school.za/php/circular_docs/10_ncs_electrical_technology.pdf.

Singmin, A. (2001). Beginning digital electronics throüh projects. U.S.A.: Newness.

The Solent Electronic Home (2011). Home theatre systems. Retrieved 15/04/14, from http://www. thesolentelectronichome.co.uk/home-theatre-systems/index.html.

Theraja, B. L., \& Sedha, R. S. (2009). Principals of electronic devices and circuits: Analog and digital in S.I. units. New Delhi: S. Chand and Company Ltd.

Tokhein, A. (2005). Digital electronics: Principles and applications (6 ${ }^{\text {th }}$ Ed). New Delhi: Tata McGraw Hill.

Uzoagulu, A. E. (2011). Practical guide to writing research project reports in tertiary institutions. Enugu: Cheston Ltd.

Advised by Agnaldo Arroio, University of Sao Paulo, Brazil

Received: July 09, 2015

Accepted: August 25, 2015

PROBLEMS

OF EDUCATION

IN THE $21^{\text {st }}$ CENTURY

Volume 66, 2015 